\title{
多層プリント配線板の全自動生産システムの開発
}

\author{
鈴木 政男 ${ }^{*}$, 藤掛 勝彦 ${ }^{* *}$, 井上 道也 ${ }^{* *}$, 梶川 雅夫**, 武田 等 ${ }^{* *}$
}

\section{Development of Full Automatic Production System of Multilayer Printed Wiring Board}

\author{
Masao SUZUKI*, Katsuhiko FUJIKAKE**, Michiya INOUE**, Masao KAJIKAWA ${ }^{* *}$ and Hitoshi TAKEDA ${ }^{* *}$
}

*ファナック株式会社（テ191 東京都日野市旭が丘3-5-1）

**ファナック株式会社電子回路製造部（テ191 東京都日野市旭が丘3-5-1）

*Fanuc Ltd. (3-5-1 Asahigaoka,Hino-shi,Tokyo 191)

**Electronic Circuit Manufacturing Department,Fanuc Ltd. (3-5-1 Asahigaoka,Hino-shi,Tokyo 191)

\section{寄稿にあたって}

多層プリント配線板の製造プロセスはきわめて複雑で自 動化が困難なため，従来世界各国とも程度の差はあれ，労 働集約型の生産形態をとっているのが一般的である。もし 高度な技術で単純労働を自動化し,クリーンな環境の工場 で低コスト生産ができたら，将来の業界に明るい展望が開 かれる。ファナックは約4年間にわたりこの困難な課題に 挑戦し, 最先端のED法・ダイレクトプレーティング法・ 積層法等の製造技術を確立し，また，高度な自動化技術に よって無人機仕様の各種加工装置をシステム化してライン を構築した。そしてホストからの生産指令で，自動搬送車 が倉庫から基材を最初の内層回路形成装置に供給すると， 後は連続する各工程を停滞なく加工・搬送されて出荷検查 まで全自動で完了する。ワークと治工具にはIDコードが付 いているので, 物と情報の流れが一体化され，自動加工と 共に生産管理のペーパーレス化も実現できた。こうしてい まだ例のない全自動の多層プリント配線板工場が完成し， 低コスト・短納期・高歩留りでフル操業を続けている。こ れらは, プリント板事業の空洞化回避と生き残りに1つの モデルを提供するものであると考え，本誌に寄稿した。困 難な環境の中で奮闘中の，関係各位の参考になれば幸いで ある。

\section{1. まえがき}

我が国のプリント配線板産業を回想してみると，高い品 質意識を共有する良質な労働力と意欲的な技術者・経営者 とにより，電子産業の発展に呼応して急成長をなし遂げ， 1980年代には品質・技術・生産性とも世界のトップレベル に立っていた。しかし，1990年代になると，長い不況と円 高により大きな打撃を受け，一転してマイナス成長に陥り， 設備投資や開発投資も次第に勢いを失い，産業の衰退が懸 念されるようになった。一方，台湾をはじめとする東南ア ジアの地域では, 低コストの労働力・材料・設備・エネル ギ等の恵まれた環境を活用して，かつて日本がアメリカに
迫ったような勢いで急速に発展し，年を経るごとに競争力 を高め, 日本のメーカは品質面はともかく, コストの面で は厳しい状況に直面するようになってきた。

ファナックはこのような状況を打破し，自社の商品であ るCNCやロボットにとっての重要部品一高信頼性多層板一 を安定的に確保するために, クリーンで自動化された近代 的工場の建設を計画した。部分的自動化ではなく工場全体 の有機的な自動化を目指す。どこにも負けない価格競争力 がある自動工場にする。これから建設するからには 21 世紀 にも十分通用するものにする。このような考え方でいろい ろな課題に挑戦し, 約 4 年間の長い研究開発により, 数々 の製造技術を開発し，人の動作をロボットに置き換える自 動化技術を駆使して，理想的な全自動生産システムを完成 した。工場の操業はすでに3年余におよび，改善に継ぐ改 善で品質・納期・コストのいずれの要素においても，所期 の目標を達成し，十分な競争力を持ってフル稼働してい る。

\section{2. 開発の基本方針}

これからの産業はコスト競争で後れをとったら，いかな る先端技術を駆使しても生き残ることはできない。それゆ え開発の目標を低コスト自動化の実現に置いた。至難と言 われる多層プリント配線板の自動化を実現するために，思 い切った発想の転換を行い，方針を決定した。

a.コストが高く自動化できないプロセスは採用しない。

b. 最少, 最短の工程にし, 費用は可能な限り低減させ る。

c. 将来の環境規制に該当する薬品を一切使用しない。

2.1 低コスト対策

コストを構成する，主要な3科目についての徹底削減策。

2. 1.1 人件費

1） $1 / 5$ 以下の労務費のところと戦える企業体質にする ために直接人員を $1 / 5$ 以下にする。その手段として単純労 働やハンドリング動作を，すべてロボットと自動機に置き 換えてしまう。 
2） IDコードを工場内で使うすべてのワークと治工具に 付与し, 物と情報が工程を一体になって進み, 治工具の選 択交換も加工条件管理も自動化し, 生産管理もぺーパーレ スにし間接人員も省人化する。

\section{1.2 設備費}

1）シンプルで低コストの無人仕様の装置にするため， 機能本位の設計に徹する。

2）工場を流れる基板のサイズを1つに統一し，すべて の装置の構造を簡単にする。

3）工場スペースを必要最小限にし, 設備もコンパクト にし，エネルギ費や諸経費を節減する。

4）工程を可能な限り単純にし短くするため，めっきは パネルプレーティング 1 工程のみにし，基板の仕上げ仕様 はソルダコートに統一する。

\section{1.3 材料費}

1）完全自動化と低コスト化と高密度に対応するため， 感光性ドライフィルムを使用せず，内層はネガタイプ，外 層はポジタイプの液体レジストのED法にする。

2）ダイレクトプレーティングを採用し，規制の対象に なるホルムアルデヒドを含む無電解銅を使用しない。

3）洗浄工程にトリクロロエタンを使用しない。

4）鏡板を使用しない積層法を開発する。これと関連し て当板を使用しない穴あけ法を開発する。

5）電気検查用治具に異方性感圧導電ゴムを採用する。

6）製造法と品質管理を工夫して抜群の歩留りにする。

7）無停滞のラインにして工程在庫を最少に抑える。

\section{3. システム開発の経過}

\section{1 1988年}

この基本方針とコスト削減策を実現するため，3月に工 場の構想に着手し，内外の技術情報調査から最新技術動向 を把握して，具体化の作業に入った。プロセスの選定，小 規模な実験から生産規模の実験・評価を繰り返した。

一方で専用の無人機仕様の装置の設計から製作・テスト を進め, コンピュータ統合のFMS自動化システムの構築の ための膨大なソフト開発に着手した。

\subsection{0 年}

装置の搬入・設置・試運転でレイアウトをほぼ完成し， プロセスの本格的生産テスト・評価に取り組んだ。実験と 生産との間には超えねばならない厳しい壁があり，特に前 例のない新技術を導入したプロセスにおいて，難しい問題 が発生し，その解決に予想以上の時間を費やし，工場の完 成を遅らせることになった。

難航した代表的な問題点を列挙すると次の通りである。 これらの解決・改善の内容については次章で述べる。

3. 2. 1 プロセス

1） ED法：液体感光性レジストの電着液から, 強くて 無欠陥の膜を得ること。液を安定にすること。
2）銅／銅䈃：積層から穴あけ加工中は密着していて， 鏡板と当板の役割を果たし，用済み後は自動機で確実には く離できる接着強度にコントロールすること。

3） ダイレクトプレーティング：スローイングパワーが 優れ，ボイドのないめっき層が得られ，内層接続の信頼性 の高い, 安定したプロセスにすること。

4）レジストスプレー：耐切削油性の優れたソルダレジ ストで，自動スプレー方式に適合するアルカリ現像タイプ のインクを開発すること。

5）ソルダレベラ：QFPを搭載しはんだ付けするパッド 上に均一平滑なはんだをコーティングすること。

\section{2.2 自動化機器}

全工程を連続させて停滞なく流れるラインにするため に, 独自開発の機器を製作する。

1）自動基材供給装置：コンピュータからの生産指令に より，層数別のコンテナに収容されている基材を，ロボッ トが加工装置の入口に投入するもの。

2）先入れ先出しバッファ：大工程ごとに加工終了後の ワークを, 約1時間分, 順序良く格納するもので, 次工程 にトラブルが起きた時は緊急避難用に，自工程のトラブル のときは次工程への供給用に使用し, トラブルが1時間以 内に復帰すれば後工程にラインストップを発生させずに連 続生産できるようにするもの。

3） バーコードリーダ：各工程の入口に設置しておき， コンベアでワークが搬送されてくるとワークに付いている バーコードを自動的に読み取って, 無人加工させるための ユニット。

4） ホールコードリーダ：化学処理工程などでは薬品に バーコードが侵されてしまって使えないので, 代わりに使 用するホールコード用のリーダ。

5） X線バーコードリーダ：積層によって内層上のバー コードは隠蔽されてしまい，このままでは情報が断絶する ので, X線で読み取り, プリンタで外層に転写するもの。

6）ワーク自動整列装置：穴あけ工程の前と外層工程の 前に設置し，それまでの加工中に乱れた状態になった同一 図番のワークを，IDコードで読み取りロボットで揃えて整 列棚に格納し, 後工程の治工具段取り回数を減らし生産効 率を向上させるもの。

\subsection{1年10月}

これらの開発が成功し，装置の整備も完了し，工場生産 がスタートした。操業後 1 年余りは生産技術の問題や不況 による物量の低迷等があって，赤字操業が続く。

\subsection{3年度}

総力を上げて諸改善を行い, 工場は軌道に乗り, 次第に 歩留り・生産性・コスト低減等の成果が上がり, 操業 1 年 半で黒字に転ずることができた。

\subsection{4年度〜}

長い不況を抜け出し, 受注の回復と共に生産量が急増し, 
品質・生産効率が著しく改善され, 費用は低減され, 所期 の目的通り強いコスト競争力を持つに至った。

\section{4. 開発の内容と特徵}

前章までに概説した多くの問題や開発課題について，逐 次詳述する。

\section{1 自動化に不可欠な基材の開発}

4. 1. 1 そりと寸法

連続する自動ラインの搬送の確実性を期するため，使用 する基材のそり，ねじれ，寸法変化をできるだけ小さくす ることが重要な課題である。基材メ一カと協同して素材の 加工工程・成形工程・仕上げ工程に改良を加え, そりは従 来の $1 / 2(0.3 \%)$ 以下に抑えることができ，また寸法変化 率を土0.01\%以内にすることができた。

\section{1 . 2 耐電食基材 ${ }^{1}$ （図1）}

高密度化でvia hole間, ライン間距離が次第に接近し， 使用環境が劣悪の場合は電食による絶縁劣化が起こる危険 性が増している。そこで長期にわたる改善開発に取り組み， 樹脂の純度と配合比やガラス界面の特性を改善し, 従来の 約5倍の絶縁特性を備えた基材を開発することができ，商 品化に成功した。

\subsection{3 ボイドレスPP}

低圧真空積層法においてボイド，かすれ，ミーズリング をなくし, 絶縁障害を防止し, 信頼性の高い多層成形を実 現するため，障害の原因である気泡をなくしたプリプレグ をメーカと協力して開発し, 合わせてレイアップで発生す る樹脂の粉塵を防止するための端面処理を行った。その結 果, 加工環境の著しい改善と, エポキシスポットによる不 良や打痕を大幅に低減することができた。

4. 1.4 銅キャリア付きUTC䈃（図2）

積層自動化を実現するため, UTCがロボットで取り扱え しかも外層回路の傷不良を防止できるという，画期的な特 徴を持った外層材の開発を行った。5〜9 $\mu \mathrm{m}$ のUTCと支持 特性

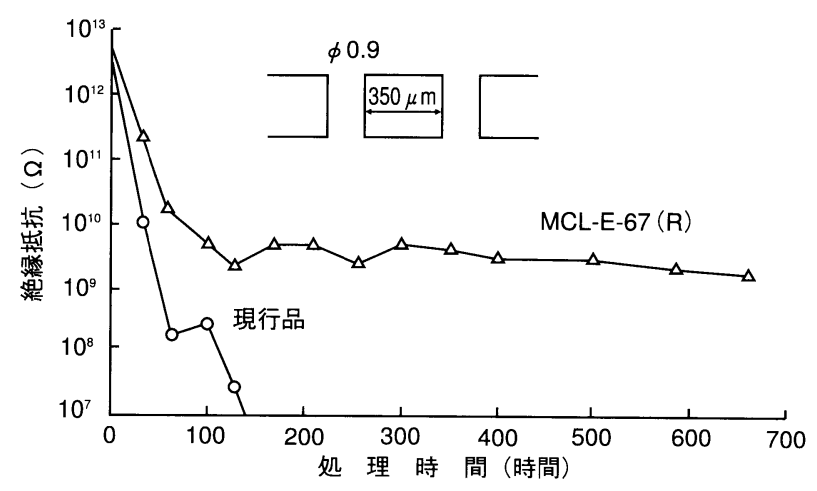

特徵 1. 樹脂配合の改良により、めっき銅の溶出量を低減

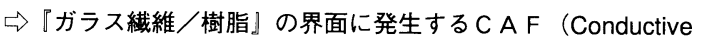
Anodic Filaments）低減による絶縁信頼性の向上

2. $85^{\circ} \mathrm{C}, 85 \%, 100 \mathrm{~V}$ 印加 ( $\left.\mathrm{TH} / \mathrm{TH} 350 \mu \mathrm{m}\right)$ で600時間以上

図1. 耐電食基材の試験結果
する $70 \mu \mathrm{m}$ のキャリア銅䈃のマット面・シャイニー面とピ 一ル界面の, 析出結晶の成長技術や粗化のための電解処理 条件を改善して, ピール強度を $50 \sim 120 \mathrm{~g} / \mathrm{cm}$ の範囲にコン トロールして接着する技術を確立して, 自動ピーラを含め 実用化に成功した。キャリアを背合わせしてスポット溶接 して使うことにより, レイアップの高能率化と樹脂粉の付 着防止ができ, さらに鏡板なしの積層成形を実現し, 次の 穴あけ工程では, エントリフォイルとしてのアルミ䇴を省 略でき, 世界で初めて積層一穴あけ工程の一貫した全自動 化に道を開いた。

\section{2 プロセス技術の開発}

当工場で採用したプロセスの中で特徴のある, ED法, 自動AOI検査, 積層, 穴あけ, めっき, 仕上げ加工および 電気検查について, 工程順に記述する。

\section{2. 1 ED法 ${ }^{2)}($ 図3)}

高密度回路技術の進歩を予測して, ドライフィルムの解 像度の限界を超える, 電着フォトレジスト法（ED法）を 選び, 内層も外層もフォトレジストはEDだけに絞り，実 用化に挑戦した。

内層はネガタイプのカチオン型の液状レジストで，ポリ マーがコロイド状分子やミセルを含むエマルジョンの形を とり，電解槽中でステンレス陽極と基材の銅箔陰極に直流 電圧をかけると, 正電荷に帯電したレジスト分子が, 電気 泳動で銅䇴上に析出凝固する。これを加熱乾燥するとレべ リングされて平滑な $6 \mu \mathrm{m}$ 前後のレジスト膜が得られる。

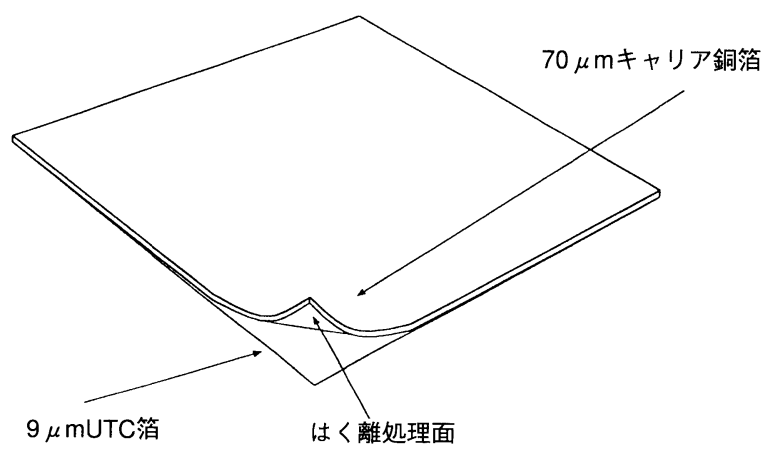

図2. $70 \mu \mathrm{m}$ 銅箔 $/ 9 \mu \mathrm{mUTC}$ 箔
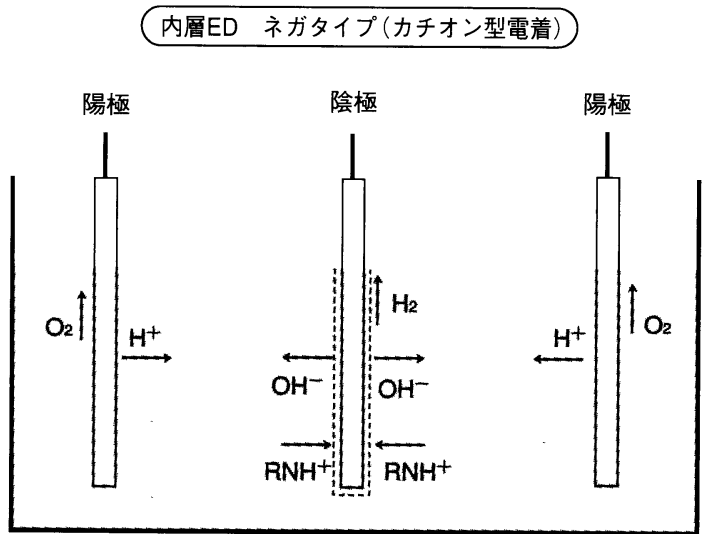

図3. ED法の原理 
外層はポジタイプのカチオン型の液状レジストを用い， 穴あけ・めっきを終わった基板を陽極に配置して電着する

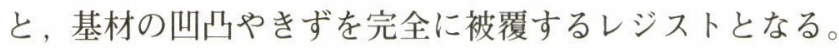
ポジであるから露光した部分がアルカリに溶解し, 保護し なければならない小径スルーホールの内壁の部分のレジス トは，エッチングが終了するまでは強固に密着している。

両者とも約 3 年に及ぶ央験・評価を繰り返して，液管 理・電着条件・乾燥法を確立し，さらに弱いレジスト膜を 傷つけないよう搬送の全自動化を採用した。そしてついに 99\%を超える歩留りを達成し, 経済的にも実用化に成功し た。この工程もハンドリングから人手を一切省くことがで きたのが, 成功の一因であると思う。

重要管理項且

1） NV (加熱残分)，溶剤を高めに維持管理

2）現像液 $\mathrm{pH}$ の連続モニタリング

3）使用前フィルムのAOI検査

4）装置全体の念入りな $5 \mathrm{~S} / \mathrm{PM}$ 励行

4. 2 . 2 自動AOI検查 (困4)

高密度回路をイメージセンサでパターン認識し, 特徴抽 出法で高速高精度に検查するAOIは世の中に多いが，それ らの中から自動ラインに向くものとして，搬送機構のつい た機種を選定し，ソフト・ハードに改善を加えて性能を向 上させ, 表面回路用と裏面回路用を2台シリーズに配置し, 省人化された停滞のない検査システムを構築した。自動ラ インの効率化の阻害要因は不良と疑似欠陥である。改善に よってこれらをゼロに近づけることが課題である。

\section{重要管理項且}

1）回路設計の線端処理を徹底

2）銅回路の防錆処理を確立

3）防除塵の徹底

4. 2.3 積層 (困5)

検査をパスした内層は酸化銅処理をした後, コンベアで レイアップ室に進入する。入口でバーコードリーダが内層 の図番を読み取るーコンピュータの指令で, ロボットが待 機している積層金型にダミ一板をセットする一前述の銅キ ヤリア付きUTC䇴を重ねるーボイドレスプリプレグを所定 枚数のせる一内層を重ねる一またボイドレスプリプレグを 重ね内層を重ねるーこれを層数分だけ繰り返し, 銅キャリ

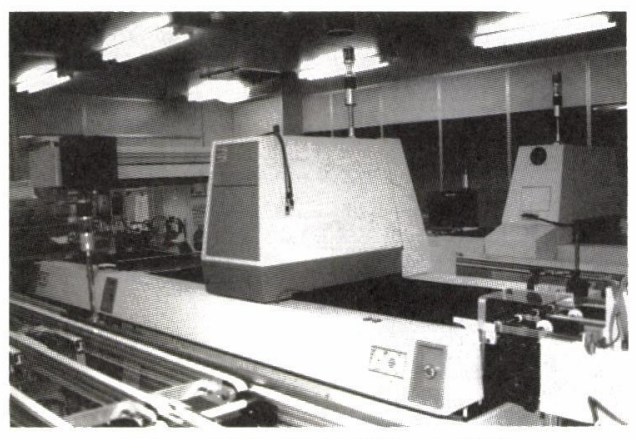

図4. 内層回路の自動AOI検查
ア付きUTCを重ねるーこのサイクルを10数ページ分繰り返 して，最後に上金型をセットしコンベアに並べる一真空積 層プレスの段数分だけ揃うとロボットでプレスに送入され るープレスが終わりアンロードされた積層板は, 自社製の 自動セパレータで1枚ずつ分離される一積層板はトリミン グされた後，バッファにストックされて完了する。一方， 積層金型は清掃ロボットで表面もガイド穴も丹念に異物が 除去され，再びレイアップ室に還流・使用される。

重要管理項且
1）銅 $/$ 銅キャリア筞のピール強度
2）金型の精度管理
3）レイアップ装置・セパレータのPM

\section{2.4 穴あけ (図6)}

ワークが積層後のバッファから1枚ずつ搬出されるーX 線バーコードリーダで図番を読み取ると，印刷したバーコ ードラベルを外層上に貼付するーロボットが図番を認識し 小径穴のあるワークは2枚重ね, ないワークは3枚重ねて自 動ピン打ちされ，コンベアで穴あけに送られるーボール盤 のスピンドルへッド数の分だけたまると, AGVがコンピ ュータの指令通り運んで行く。

十数台のボール盤はループ状に配置され, ホストコンピ ユータとDNC 1 プロトコルによりCNC群管理で運転されて いる。AWCからワークが供給されると，ボール盤はワー クに付いているバーコードを読み取り, 加工情報をホスト コンピュータから呼び出して自律的に加工をする一終了し たワークはAGVが受け取って帰り，ピンを抜いてロボッ トが1枚ずつピーラに投入するーここで積層・穴あけを通 じて大切な役割を果たしたキャリア銅箔は自動はく離さ

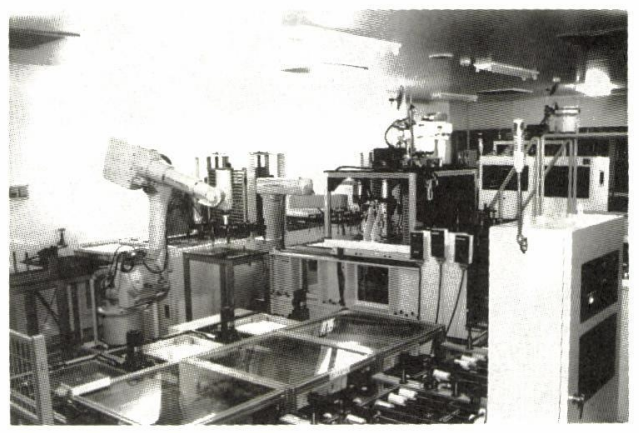

図5. ロボットによるレイアップ

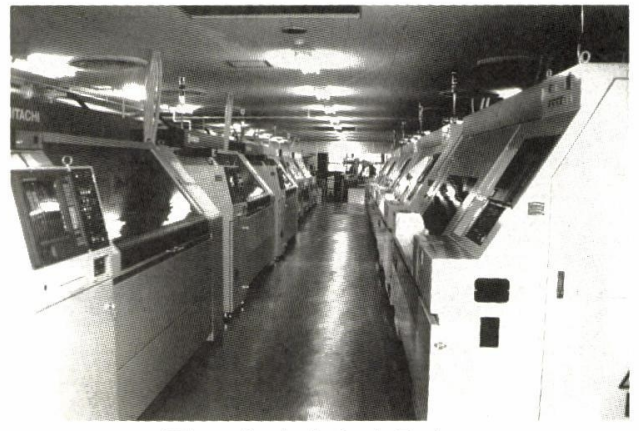

図6. 無人穴あけライン 
れ，基板は整面工程に進む。

重要管理項且

1）全スピンドルヘッドの有効活用のための整列

2）24時間ノートラブル無人稼働

3） ボール盤と搬送の定期メンテナンス

4. 2. 5 めっき（罒7）

めっきは当システムの中でも，プロセス確立に最も苦心 した工程である。無電解銅めっき液中のホルムアルデヒド やキレート化合物が環境や人体に好ましくない影響を与え るといわれ，一部欧米の先進国において使用を規制する動 きが始まっており，21世紀には使用できなくなる影念もあ る。そこで無電解銅めっきに代わる方式としてダイレクト プレーティング法を導入した。多層板に全面採用するため 長期にわたる研究を行った。量産経験にもとづく参考資料 のない当時，すべてが自社技術陣の実験・評価データの積 み上げが頼りであった。他に代わるべき補助ラインを考え ず，3年余の長期にわたり，数十回の実験・評価を経て各 種の問題を解決し，軌道に乗せることができた。

\section{重要管理項且}

1）デスミア液の電解管理

2）中和液の活性剤の洗浄性

3）導電化溶液の最低必要濃度の自動補充管理

4）ソフトエッチング溶液の適正濃度自動補充管理

5）内層銅表面の活性化と維持

4. 2.6 仕上げ工程 (ソルダマスク・マーク印刷・ソ ルダコート)

めっきを施されたワークは, 外層フォトエッチング工程 で回路形成され, 外形のルータ加工を経て, AOIにより外

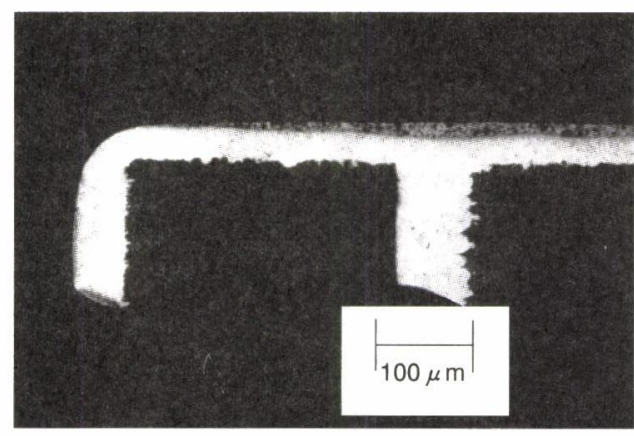

図7. めっきと内層銅界面の接続

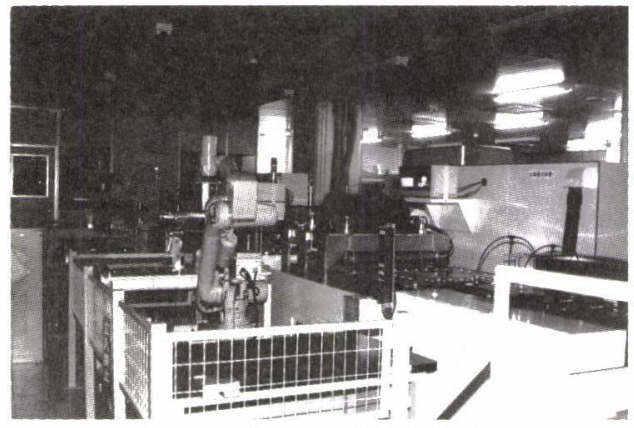

図8.レジスト自動露光装置
層パターンが検査されたあと，仕上げ工程に入る。

ワーク表面は整面され, 連続自動スプレーコーティング でアルカリ水溶性レジストを塗布し, 自動アラインメント 機構付き露光装置（図8）で露光し, 現像・乾燥する。

部品マークは自動版交換機能を備えた全自動スクリーン 印刷機で印刷される。

最後に, 実装のための予備はんだのコーティングは, 平 滑均一なはんだを水平式ホットエアレベリング装置（図9） を用いて行い，多層プリント配線板が完成される。

4. 2. 7 電気検査 (困10)

すべての加工が完了した多層板は，全数電気検査される。 SMT多層プリント配線板の検査は, 図番ごとに専用検査治 具を必要とし, 従来の接触プローブ方式では段取りを含め た無人化はほとんど不可能に近い。そこで, 異方性感圧導 電ゴムをインタフェースボードとセットにした治具を採用 した。当日使用する検查治具を格納ラックに収容しておき， 工程の人口で基板のバーコードが読み取られると，ロボッ トが格納ラックから該当治具を取り出し，検査台にセット し, 次に基板を運んできて, ビジョン整合位置合わせ装置 で両者を正確に重ね，CADデータで十数秒で検査を行い合 否を判定する。これらの無人ユニットの統合で初の全自動 検査ラインを実現することができた。

\section{5. 全自動生産システム}

\section{1 自動化の基本方針}

1）初工程から完成まで無停滞の連続一貫ラインとする

2）単純繰り返し作業やハンドリングから人手を解放する

3） IDコードの採用で物と情報の流れを一体化する

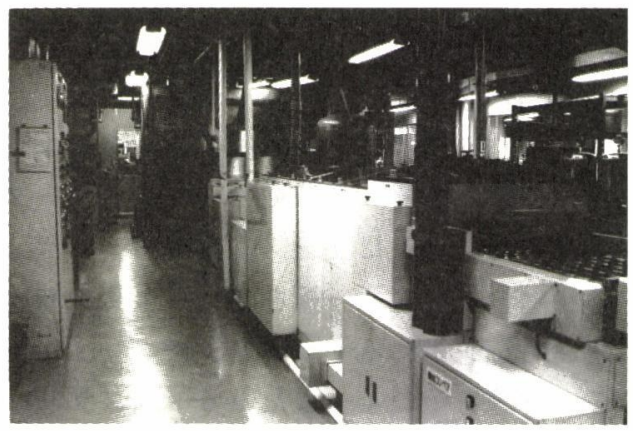

図9. 水平型ソルダレベラ

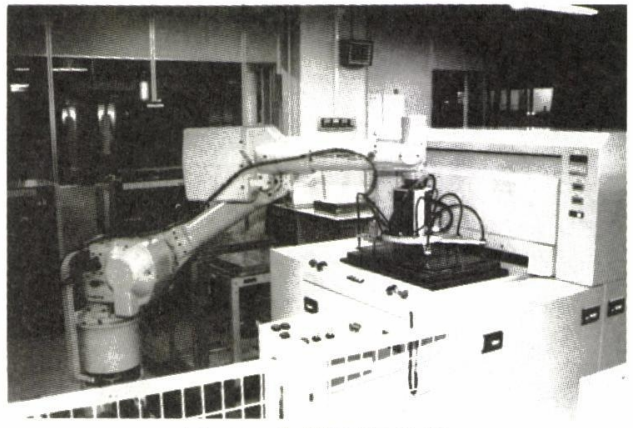

図10，自動電気検查 
この方針に沿って, 約4年の歳月をかけて開発した前述 の各種最新技術と無人機は，コンピュータシステムによる 統合で多品種少量生産にも対応できる，フレキシブルな全 自動製造ラインとして完成した。

\section{2 生産管理}

生産オーダはホストコンピュータからLAN経由で工場ホ ストが受け, 生産計画・生産指示・治工具準備・諸材料の 発注を行う。

LANで接続された工程パソコンが，各工程ごとに設置さ れているIDコードリーダからの情報で, リアルタイムに進 渉管理，工具交換，治具交換を自動で行う。

PM情報は部品寿命管理, 故障部品の原因統計を行う。 原価管理データとして主材料, 補助材料, 消耗治工具等の 発注・在庫・消費量の集計を行う。

\section{3 CAM情報の一元供給管理}

本社CADシステムと全社LAN／工場LANの結合により， $\mathrm{CAD} / \mathrm{CAM}$ データの一元供給管理を行っている。ファイ ル転送されたデータにより，フォトマスク・CNCデータの 作成と供給を行う。

\section{4 工程監視}

最適なプロセスコントロールを行い，品質の作り込みと 不良防止を行うため, 各装置は自動分析計・圧力計・流量 計・積算電流計等の維持管理センサを設置して監視し，管 理限界に近づくと異常アラームを出し, 限界を超えると自 動的に停止する機能を設けた。

\section{5 製造自動化システム（図11）}

各工程は工程管理セルによってコントロールされる。セ ルは工程パソコン・ID*1コードリーダ・PLC・ロボットコ ントローラによって構成されている。前工程からワークが 到着すると, 入口でIDコードリーダが読み取り，その情報 が工程パソコンに入り，工場ホストから加工情報を呼び出 し，同時にPLCに制御情報を伝え，無人加工機・ロボッ ト・コンベア・バッファが制御され，自律的に加工が行わ れる。同時にワークの流れに同期して，工程状況がホスト に送信され, 稼働状況・進渉状況が収集され, ペーパーレ スで管理される。

\section{6 工場レイアウト図（図12）}

このような自動工程を工程順に連続ラインに集大成した ものを工場レイアウト困に示す。工程（番号）順に説明す ると, まず, 受注データから作成したホストコンピュータ の生産計画にもとづく投入指令で, 自動倉庫〔1]から基 材がAGVに積載され, ロボットで最初の工程である内層 回路形成ライン〔2〕に供給され, 電着・露光・現像·工 ッチング・はく離・乾燥後ガイド穴加工する。次に内層検 查〔3〕室に進みAOIで回路欠陥を検査する。積層〔4〕で は銅䈃・PP · 内層材を重ねてプレスされる。穴あけ〔5]

脚注 $※ 1 ：$ ID

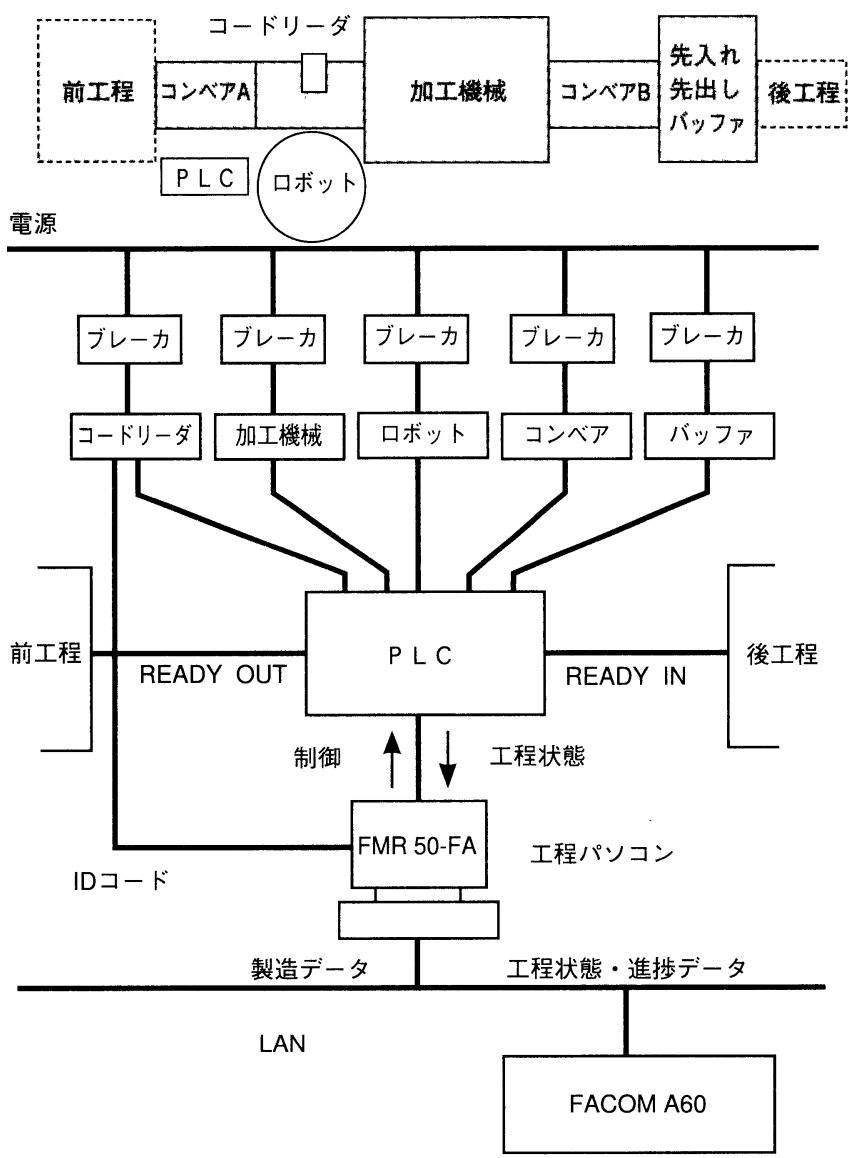

図11. 詳細な工程自動化モデル

は群管理により24時間無人で加工が行われる。電解めっき 〔6〕はダイレクトプレーティングを採用した。ここまでが 1階で，めっきされた基板は2階に自動搬送し，外層回路形 成〔7〕でポジのEDを用いて高密度加工をし，外形加工 〔8〕ではルータで精度よくスリット加工をし，外層検查 〔9]でAOIにより断線・欠け・残金を検査し，欠陥を修正 する。ソルダマスク〔10]では銅回路部分をコーティング し，マーク印刷〔11〕で部品のシンボルと文字を自動印刷 し，ソルダレベラ〔12〕では予備はんだを薄く被覆して， 最後に出荷検查 [13] 工程で電気検査と目視検査を行う。 その後, 所定の条件で除湿乾燥し真空包装して出荷する。 以上の工程がすべて工程モデルで示した無人仕様の自動シ ステムをインテグレートした，一貫全自動ラインとなって いる。

\section{6. 開発の成果}

ここに初めて紹介した，多層プリント配線板の全自動生 産システムは，工場生産開始以来3年余り経過して順調に フル操業しており，次のような成果が得られている。

(1) 品質

工程管理の充実と人手の解放により品質は安定し, 歩留 りは97\%台で, SMT多層のみの工場としては高い水準にあ る。 


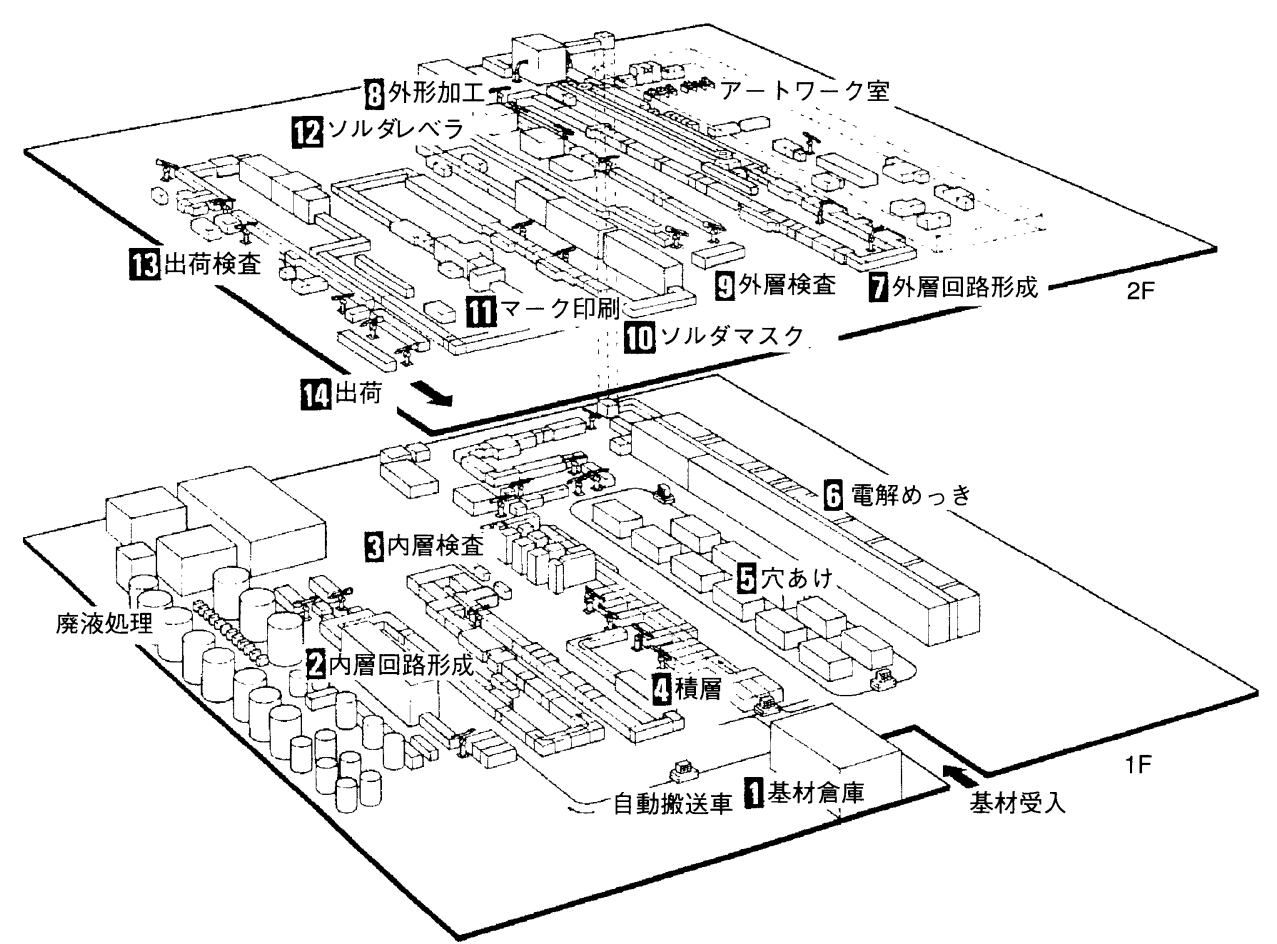

図12. 全自動工場レイアウト

(2) リードタイム

連続ラインのため特急 2 日，通常5日で大幅な短縮となり， 在庫の削減や新製品の開発期間の短縮にも寄与している。

(3) $3 \mathrm{~K}$ からの転換

これまでのプリント配線板工場の暗いイメージを一変し て清潔でクリーンな環境になり，仕事の内容は，知的なも のが主になった。

（4）ロボットによる省人化

35台のロボットが人の単純労㗢にとって代わり，人件費 格差によるコスト競争力の低下という課題を解決し，材料 経費の削減効果と相まって外地生産の必要はなくなった。

\section{7. むすび}

当工場は生産性, 納期, コストとも，建設当初に設定し
た目標を達成し，品質信頼性も高く，採算性は良好である。 しかし技術の進歩の速い現在は，開発が完成した時が陳腐 化の始まり，といわれる。今後も新技術を学び，時代と共 に進化する工場に発展してゆくよう努力を続ける必要があ る。

(1995.3.10-受理)

\section{文献}

1）村井 曜, 他：“高密度配線板用耐熱性改良多層材料MCLE-67（Y)”，日立化成テクニカルレポート，No.20,pp.23〜 26,1993-1.

2）木村俊哉，他：“ピン間5本プリント配線板の量産化”, NEC技報，Vol.45,No.9,pp.77〜81,1992-9. 